\title{
Bilimlerde Düşünce Deneyleri
}

\author{
Thought Experiments in the Sciences
}

\begin{abstract}
Mustafa Efe ATEŞ ${ }^{*}$
Öz: Düşünce deneylerine bilimlerde sıkça rastlanmaktadır. Bu deneylerin kullanımı her ne kadar Sokrates öncesi döneme kadar götürülebilse de, on yedinci yüzyılın başından itibaren Galileo, Newton ve Leibniz gibi bilim adamları bu zihinsel araçların önemini kavramıştır. Günümüzde ise, şüphesiz görelilik fiziği ve kuantum mekaniğinde düşünce deneyleri merkezi bir role sahiptir. Bu makalenin amacı bilimsel akılyürütmenin bu önemli aracını felsefi bir noktadan hareketle incelemektir. İlk olarak düşünce deneylerine ilişkin kısa bir tarihsel arka plan sağlayarak, bilimlerde kullanımı ele alacağım. Daha sonra iyi bilinen bir düşünce deneyi örneği üzerinden bu deneylerin sergilediği temel özellikleri göstereceğim. Son olarak, düşünce deneylerinin sahip olduğu birçok temel işlevi bazı örnekler üzerinden inceleyeceğim.
\end{abstract}

Anahtar sözcükler: Düşünce Deneyleri, Ernst Mach, Pierre Duhem, Bilim Felsefesi, Epistemoloji

Abstract: Thought experiments are ubiquitous in the sciences. We can trace their use back to the age of the Pre-Socratic philosophers, but from the start of the seventeenth century onwards, scientists such as Galileo, Newton and Leibniz recognized the very great importance of these mental instruments. To be sure, in our own time, thought experiments play a pivotal role in relativistic physics and in quantum mechanics. This paper aims to investigate these important instruments of scientific reasoning from a philosophical point of view. Firstly, a short historical background is presented concerning thought experiments and their use in the sciences is discussed. Secondly, a well-known example is presented, in order to show some of the common features of thought experiments. Finally, through the presentation of several examples, some of the basic functions of thought experiments are exhibited.

Keywords: Thought Experiments, Ernst Mach, Pierre Duhem, Philosophy of Science, Epistemology

\section{Düşünce Deneyi Teriminin Literatürdeki İlk Kullanımı}

Düşünce deneyi terimini ilk olarak ortaya atan kişi Ernst Mach olarak bilinmektedir. 1896 y1lında fizik ve kimya eğitimi ile ilgili olan 'Zeitschrift für den Physikalischen und Chemischen Unterricht' dergisinde yer alan 'Über Gedankenexperimente’ isimli makalesinde Mach, bu deney tipine ilişkin şu ifadeleri kullanmaktadır:

Gerçek fiziksel deneye ek olarak, yaygın bir biçimde ve daha yüksek bir entelektüel düzeyde yürüttüğ̈̈müz bir diğer deney de, isim vermek gerekirse, düşünce deneyidir (Mach 1897/1973, 451).

Ancak düşünce deneyi teriminin, literatürde ilk ifade edilişinin çok daha önce olduğunu savunanlar da bulunmaktadır. Örneğin Witt-Hansen (1976) söz konusu terimi ilk kullananın Hans Christian Ørsted olduğunu iddia etmektedir. Ona göre Ørsted, Immanuel Kant'tan esinlenerek,

\footnotetext{
* Arş. Gör., Muğla Sitkı Koçman Üniversitesi, Edebiyat Fakültesi, Felsefe Bölümü, Muğla. mefeates@mu.edu.tr
} 
düşünce deneylerinin doğa kuramları ile birliktelik ilişkisine dikkati çeken ilk kişidir.

Şeyler hakkında gelişme, düşüncelerin gelişmesiyle birlikte hareket eder ve bu birliktelik doğa kuramının özünü oluşturur, bu gelişim süreci ise bir kimsenin, şimdiye kadar gözden kaçmış olan, düşünce deneylerine başvurma zorunluluğuna kanit oluşturmaktadır. Bu durumla ilgili en güzel örnekler, kendisi her ne kadar bu ayrıntıya dikkati çekmese de, bize Kant tarafindan bahşedilmiştir ve Doğa Bilimlerinin Metafiziksel Temelleri adlı eserin içerisinde sergilenmektedir (akt. Witt-Hansen 1976, 63).

Fakat Witt-Hansen'e (1976, 62-63) göre Ørsted, terimi literatüre sokan ilk kişi olmasına rağmen, bu zihinsel etkinliğe denk düşecek herhangi bir bilim-tarihsel örnek vermemiştir. Ørsted düşünce deneylerinin "yaratıcı bilimsel çalışmada nasıl bir role sahip olduğunu ve onun bilimde hipotezlerin ve varsayımların kullanımındaki ilişkisini bir ölçüde detaylı olarak tartışmıştır. Bu dikkate değerdir ancak metninde ne tek bir düşünce deneyini ne de 'gerçek' bir deneyi analiz etmiştir. 'Genel Doğa Kuramının Tarihi' isimli kısa çalışmasında Archimedes'ten Newton'a uzanan matematiksel fiziğin kurucuları tarafindan sağlanan zengin kaynaklarda bulunan örneklemlerden faydalanmamıştır".

Şu halde düşünce deneyleri terimini ilk kullananın Ørsted fakat bilimdeki statüsünü bilimtarihsel örneklerle destekleyen ilk kişinin de Mach olduğu söylenebilir. Elbette düşünce deneyi olarak ifade ettiğimiz zihinsel etkinliğin literatürde tarih boyunca birçok farklı terimle karşılandığını da burada ayrıca belirtmek gerekmektedir. 'Hayali deney', 'imgesel deney' ya da 'kurgusal deney' gibi ifadeler bu farklı terimlerin yalnızca birkaçıdır. Ancak günümüzde artık düşüncede yürütülen deneyler, yerleşmiş bir şekilde 'düşünce deneyi' olarak ifade edildiğinden ve Mach tarafından ilk kez bağımsız olarak 'düşünce deneyi' terimi altında incelendiğinden, terimin ortaya çıkış tarihini on dokuzuncu yüzyıldan başlatmak daha uygun olacaktır.

\section{Düşünce Deneylerinin Doğasına İlişkin İlk İnceleme ve Eleştiri: Ernst Mach \& Pierre Duhem}

Düşünce deneyini, terim olarak ilk kullanan kişi olmamasına rağmen, bu zihinsel etkinliğin doğasına ilişkin ilk detaylı incelemeyi Mach yapmıştır. Dolayısıyla Mach'ın düşünce deneyleri hakkında öne sürdügü görüşleri incelemek, günümüzdeki tartışmalara ışık tutması bakımından, önemlidir.

İlk olarak Mach'ın empirist-duyumcu bir çizgide olduğunu belirtmek gerekmektedir. Ona göre doğanın bilgisi deneyim yoluyla elde edilir, deneyim ise duyumların toplamıdır. Fakat deneyim yoluyla elde edilen bilgiler, doğanın kendi iç yapısından dolayı, doğrudan anlaşılabilir değildir. Kendi ifadeleriyle (Mach 1919, 28):

Doğada gözlemlediğimiz her şey, kendisini, algılarımıza ve düşüncelerimize, anlaşılır olmayan ve analiz edilmemiş olarak tanıtır [ancak] sırası geldiğinde, doğanın işleyişini, sahip oldukları en genel ve en çarpıcı özellikleriyle taklit eder. Sahip olduğumuz bu birikmiş deneyimlerin içerisinde, ilk elde kapalı ve yalnızca küçücük bir kısmı eklemlenmiş düşünce olarak konumlanan bir tür hazine ya da depo bulunmaktadır.

Başka bir deyişle zihnimizde, doğanın henüz anlaşılır olmayan ve analiz edilmemiş bilgisi, keşfedilmeyi bekler bir halde depolanmıştır. Mach bu zihinsel deponun içerisinde ilk olarak kapalı fakat daha sonra özgür kalacak olan bilgiyi, içgüdüsel bilgi (instinctive knowledge) olarak adlandırır. İçü̈düsel bilgi güvenilirdir; fakat açık bir bilgi değildir ya da daha önceden edindiğimiz açık bilgilere henüz eklemlenmemiştir. Onu özgür bırakarak, diğer açık bilgilerimiz ile 
eklemlemek Mach'a göre ancak düşünce deneylerinin işlevidir. Böylece empirik yoldan sahip olduğumuz ham veriler, düşüncenin rehberliğinde işlendiğinde yeni sonuçlar elde etmemize yardımcı olacaktır.

Mach'a göre düşünce deneylerinin işlevi yalnızca, içgüdüsel bilgiyi daha açık hale getirmekle sınırlı değildir. Bunun yanında fiziksel deneyleri önceleme ve onun her ne kadar mantıksal anlamda olmasa da zorunlu bir ön koşulu olma işlevlerine de sahiptirler:

[D]üşünce deneyleri çoğu kez fiziksel deneyi önceler ve onun yolunu açar... Bununla birlikte, bir düşünce deneyi aynı zamanda fiziksel deneyin zorunlu ön koşuludur. Her mucit ve deneyci, deneyini gerçekleştirmeden önce, zihninde deneyin ayrıntılı düzeneğine sahiptir. Stephenson trenin, rayın ve buhar makinesinin tek tek ne olduğunu deneyimle bilmesine rağmen yine de [icadını] gerçekleştirmeden önce, düşüncesinde tekerlekleri üzerinde buhar makinesiyle çalışan tren kombinasyonunu önceden düşünmüştü. Yine aynı şekilde Galileo, yer çekimini incelemeyi düzenleyebilmek için, deneyi gerçekleştirmeden önce, hayal gücünde bazı tasarımlar yapmak zorundaydı (Mach 1897/1973, 452).

Düşünce deneylerinin sıklıkla fiziksel deneyleri öncelemesi ve fiziksel deneylerin zorunlu bir ön koşulu olması iki ayrı iddia olarak yorumlanabilir. Mach'ın ilk iddiası, bir deneycinin, dış dünyada gerçekleştireceği deneyi yürütmeden önce zihninde söz konusu deney sürecini ve deneyden elde edebileceği sonuçları yaklaşık olarak tasarlaması ile ilgilidir. İkincisi ise fiziksel olan bir deneyin sahip olacağı deney düzeneğinin, deney yürütülmeden önce, zihnimizde kurulmasının zorunlu bir ön koşul olduğu ile ilgilidir. Yani dış dünyada yürütülecek bir deneyde ne tür dış koşulların sağlanacağı, parçaların nasıl bir araya geleceği ve hangi gereçlerin ne zaman kullanılacağının düşüncede, deney yapılmadan önce, iyice belirlenmesi gerekmektedir.

Önceleme ile ilgili iddianın akla yatkın olduğu öne sürülebilir çünkü yalnızca fiziksel bir deneyi yürütmek için değil, gerçekleştirmeyi planladığımız deneyi yönetebilmek için de önceden titiz bir biçimde düşünürüz. Bir yolculuğa çıkmadan önce, otomobilimin hızını ve yolda vereceğim molaları hesaba katarak, hedeflediğim şehre ne kadar süre sonra varacağımı ve ne kadar litre benzin harcayacağımı zihnimde önceden tasarlayabilirim. Kuşkusuz, otomobilimle zihnimde yaptığım bu yolculuk, bana gerçekte yapacağım yolculuk için, eğer büyük bir rastlantı olmazsa, tam olarak hedeflediğim şehre ne zaman varacağımın ya da ne kadar litre benzin harcayacağımın kesin bilgisini vermez. Kesin ve belirgin bir bilgi elde edebilmem için otomobilime binerek yolculuğa gerçekten çıkmam gerekmektedir, tıpkı bir deneycinin bazen "daha kesin ve belirgin sonuçlar almak için [...] fiziksel deneyi gerçekleştirmesinin zorunlu olması [gibi]” (Mach 1897/1973, 452). Bu durum, bir anlamda bazı düşünce deneylerinin kimi zaman gerçek deneylere gereksinim duyabileceğini göstermektedir. Yani bazı düşünce deneylerinden elde ettiğimiz sonuçlar, beklentimizin altında kaldığında "düşünce deneylerinin doğal uzantısı olan fiziksel deneyler devreye girer deneyin sinırlarını çizer" (Mach 1897/1973, 452). Diğer taraftan Mach'a göre, bir düşünce deneyinin beklenen sonucu kesin ve belirgin olarak verdiği durumlar da olabilir. Böylesi bir durumda, fazladan bir fiziksel deneyi gerçekleştirmenin gereği yoktur.

Öte yandan ön koşul olma ile ilgili iddia ise, önceleme iddiasına göre, tartışmaya daha açıktır çünkü Mach'ın burada düşünce deneyi olarak sözünü ettiği, deneyin zihinde yürütülmesine ilişkin bir görüşten daha çok, deneyde ne tür gereçlerin ve ne tür koşulların sağlanacağıyla ilgili bir tasarımlamadan fazlası değildir. Eğer Mach yalnızca, bu türden bir ön koşulun, her fiziksel 
deney için zorunlu olduğuna değinmiş olsaydı, oldukça yerinde bir noktayı aydınlatmış olacaktı. Ancak Mach fiziksel deneyleri yürütmeden önce bu deneylere ait gereç ve koşul bilgisine tek tek ya da bir bütün olarak sahip olmayı -yani zihnimizde söz konusu deneye ilişkin yaptığımız ön hazırlığı- bir düşünce deneyi olarak tanımlayarak fazlasıyla güçlü bir iddia ortaya atmaktadır.

Mach'ın bu incelemeleri ışığında, düşünce deneylerinin sahip olduğu işlevler üç farklı açıdan değerlendirilebilir. İlki, doğayı deneyimleyerek elde ettiğimiz fakat anlaşılır olmayan ve analiz edilmemiş bilgiler, düşünce deneyleri aracıllğıyla, ortaya çıkabilir. Yani fazladan bir fiziksel deneye gereksinim duymadan, düşünce deneyleri aracılığıyla, daha önceden elde etmiş olduğumuz fakat kesin ve belirgin olmayan bilgileri açık hale getirerek yeni bir bilgi elde edebiliriz. İkincisi, bazı düşünce deneylerinin kesin ve belirgin sonuçlar veremediği ile ilgilidir. $\mathrm{Bu}$ durumda, düşünce deneylerinin erişemediği kesin sonuçlara fiziksel deneylerin yardımıyla erişilebilir. Üçüncüsü ise fiziksel bir deneyin nasıl yapılacağına ilişkin zihinsel ön hazırlığın, gerçek deney için zorunlu bir ön koşul olduğu ve aynı zamanda, bir düşünce deneyi olarak değerlendirilebileceğidir. Ne var ki, fiziksel deney öncesi zihinsel bir ön hazırlığın her deneyci için bir ön koşul olduğu iddiası oldukça doğru iken bu sürecin bir düşünce deneyi olduğunu iddia etmek bu türden deneylerin epistemik statüsünü göz ardı etmesi bakımından problemli gözükmektedir.

Düşünce deneylerinin Mach tarafından öne sürülen birçok önemli işlevine rağmen, bu görüşlerinin bazı bilim adamları ve hatta bilim felsefecileri arasında kabul görmediğini söylemek yanlış olmayacaktır. Örneğin düşünce deneylerinin kullanımına radikal bir biçimde karşı çıkanlardan biri ünlü fizikçi ve felsefeci Pierre Duhem'dir. Duhem, düşünce deneylerinin güvenilir olmadığını ve özellikle fizik eğitiminin içerisinde yer almaması gerektiğini iddia etmektedir. Ona (Duhem 1954, 202) göre, "böylesi kurgusal bir deneye başvurmak yapılmış bir deneyi, deney yapmanın yerine önermektir: bu da, bir ilkeyi, gözlemlenen olgular aracıliğıyla değil, tahmin edilen olgular aracıllğgyla temellendirmektir”. Duhem'e göre, düşünce deneylerinin bu niteliği iki önemli probleme yol açmaktadır:

Bazen, bir fizikçi tarafindan tanımlanan kurgusal deney, kesinlikten uzak sonuçlar verir; tam da bu kesinlikten uzak kabataslak sonuçlar gerekçelendirilme iddiasında olan önerme ile şüphesiz uyuşacaktır; fakat bu sonuçlar ayrıca bambaşka önermelerle de uyuşacaktır; böylelikle bu türden bir deneyin kanitlama gücü oldukça zayıf ve uyarıya açık olacaktır [...] Fakat daha kötü durumlar da vardır. Başvurulan kurgusal deneyler çok sik olarak gerçekleştirilmezler, ancak bu bir tarafa, gerçekleştirilebilir olmaya da elverişsizdirler; bu deneyler doğada karşılaşmadiğımız cisimleri ve hiçbir zaman gözlemlenmemiş fiziksel özellikleri önceden varsayarlar (Duhem 1954, 202).

Anlaşılacağı üzere Duhem için kesin olmamak (imprecise) ve gerçekleştirilemez olmak (unrealizable) iki ayrı problemken, bunun tersi aynı zamanda iki ayrı güvenilirlik ölçütüdür de. Kendi deyimiyle kurgusal deneyler, yani düşünce deneyleri, kesinlik ve gerçekleştirilebilirlik ölçütünü sağlamadıkları için güvenilir zihinsel araçlar değildirler. Duhem'in bu eleştirilerine iki açıdan karşı çıkmak mümkün gözükmektedir. İlkin, düşünce deneylerinin fizik eğitiminde yasaklanmasından daha çok teşvik edilmesi gereklidir. Yakın zamanda yapılan bir araştırmaya göre, düşünce deneylerinin fiziksel ya da gerçek deneyleri yürütme esnasında önemli bir role sahip olduğu gösterilmiştir. Bu araştırmanın sonucuna göre, düşünce deneyleri öğrencilerin fiziksel bir deneye ilişkin değişimler (modifications) yapabilmesinde ve kabul gören bilimsel kavramlara yakınlaşma sürecinde onlara eşlik eder (Gilbert \& Reiner 2004). Yani Duhem'in 
deney yapmanın yerine önerildiğini savunduğu düşünce deneylerinin, aslında fiziksel deneyler üzerinde olumlu etkileri bir bakıma empirik olarak kanıtlanmıştır.

Duhem'e karşı çıkılabilecek ikinci kısım ise öne sürmüş olduğu 'kesinlik' ve 'gerçekleştirilebilirlik' gibi ilkelerin bir düşünce deneyinin güvenilirliği için uygun ölçütler olmamasıdır. Doğrusunu söylemek gerekirse Duhem'in koyduğu bu ölçütler büyük oranla belirsizdirler. Eğer kesinlik derken kastedilen şey gerçek bir deney sürecinde, gereçlerinin verdiği kesin sonuçlar ise bazen bu türden kesin sonuçlar vermeyen ve dahası gereçlerin çalışıp çalışmadığını bilmediğimiz fiziksel deney örnekleri verilebilir. Yine aynı şekilde, Duhem için daha önemli bir ölçüt olarak gözüken, gerçekleştirilemezlik kavramının da hangi amaçla kullanıldığ 1 açık değildir. Başka deyişle burada, aktüel dünyamız göz önüne alındığında, sonraki bölümlerde değineceğimiz Newton'un kovası örneğinde olduğu gibi fiziksel bir gerçekleştirilemezlikten mi, yoksa yaşadığı dönem göz önüne alındığında Galileo'nun düşen cisimler örneğinde olduğu gibi teknolojik bir gerçekleştirilemezlikten mi, bahsedildiği net değildir. Buna rağmen, tahminde bulunduğum her iki gerçekleştirilemez durum için bu deneylerin güvenilirliği test edilemez çünkü bu düşünce deneyleri tarihsel geçmişe sahip bilimsel programların birer parçasıdır. Başka deyişle deneyimle elde edilen birçok ilgili bilginin zemininde yükselen bu deneylerin güvenilirliğini böylesi belirsiz ölçütlerle sınamak yanlış gözükmektedir.

\section{Bilim ve Felsefe Tarihinde Düşünce Deneylerinin Kullanımı}

Düşünce deneyi teriminin ortaya atılışı ve bağımsız olarak incelenişi görece çok yeni olmasına rağmen bilimde ve felsefede zihinsel bir araç olarak kullanımı çok daha eskidir. Örneğin Nicholas Rescher (1991) düşünce deneylerini, varsayımsal akıl yürütme süreçlerinden bilgi edinme girişimi olarak değerlendirir ve bu tür girişimlerin örneklerine Pre-Sokratik dönem felsefesinde oldukça sık rastlayabileceğimizi iddia eder. Rescher'e göre, Thales, Phythagoras, Herakleitos ve Ksenophanes gibi dönemin önemli doğa filozofları, bu zihinsel arac1, değişik şekillerde kullanmışlardır. Farklı olarak Katerina Ierodiakonou (2005, ayrıca 2011) Arkaik ve Helenistik dönem filozoflarının, günümüzdeki anlamıyla, düşünce deneylerine başvurduklarına ilişkin bir iddianın şüpheli olduğunu savunur çünkü bu dönemin filozoflarında düşünce deneyi teriminin kendisi bir tarafa böyle bir düşünce etkinliğine ilişkin herhangi bir kavrayış bile yoktur. Elbette bu dönem içerisinde iddiaları çürütmek ya da kanıtlamak için belirli türden örnekler vardır; ancak bunlar kesin olarak birer düşünce deneyi sayılmazlar. Dolayısıyla Rescher'in görüşü çok kapsamlıdır ve "öyle görünüyor ki, düşünce deneylerinin ne olduğunu bu türden kapsamlı bir anlayışla belirlemek, kavramın sahip olabileceği her türlü açılklama gücünün kaybolmasına yol açabilir” (Ierodiakonou 2005, 129).

Orta Çağ’a gelindiğinde, bilimde ve felsefede, düşünce deneylerinin kullanılışına İlk Çağ felsefesine oranla daha sık rastlanmaktadır. Edward Grant (2010) dönemin ünlü filozoflarından Saksonyalı Albert ve Buridan'ın, ilkesel olarak gerçekleştirilebilecek deneyleri hayal gücünün alanıyla sınırlandırdıklarını öne sürer ve bu zihinsel etkinliği düşünce deneyi olarak isimlendirmenin yerinde olacağını savunur. Peter King (1991) bu görüşe paralel biçimde, dönem biliminin metodolojisinin, test etme ve gerçek deneyden daha çok düşünce deneyi olduğunu iddia eder. King'e (1991, 56) göre bu tarihsel olgu, Duhem'in modern bilimin köklerinin Orta Çağ biliminde yer aldığ 1 görüşüyle çelişmektedir. Elbette, Orta Çağ bilimi ile modern bilim arasında problemler ve kavramlar açısından devamlılık ve benzerlik bulunmaktadır "ancak bu benzerlikler Orta Çăg bilimiyle modern bilimin kullandı̆̆ metodoloji arasındaki derin ayrılı̆̆ gizlememektedir".

On altıncı ve on yedinci yüzyılda gerçekleşen bilimsel devrime kadar, düşünce deneyleri ile 
gerçek deneyler arasındaki ayrım, henüz günümüzdeki kadar belirgin değildir. Thomas Kuhn’a (1994) göre, o dönemde bazı deneyler açıkça yürütülmüşken, bazıları ise düşünce deneyinden fazlası değildir. Bu sebeple söz konusu dönemlerde deneyin düşüncede ya da gerçekte yürütülmesinin ayrıca bir önemi yoktur. Önemli olan deneyin eldeki kuramı nasıl test ettiği ya da bir doğa fenomenine ne derece doyurucu bir yanıt getirdiğidir. Ancak Francis Bacon ile başlayan ve günümüze kadar uzanan geleneğin, ölçmeyi keskin hale getirebilen gereçlerin kullanıldığ1 gerçek deneyleri ön plana çıkarmasıyla, uzun yıllar süresince, düşünce deneylerinin bilimdeki statüsü sarsılmış ve iki deney tipi arasındaki ayrım çok daha belirgin hale gelmiştir. Ne var ki "düşünce deneyleri ile gerçek deneyler arasındaki bu keskin ayrım, her ne kadar on yedinci yüzyllda belirginleşmiş olsa da, ani olarak gözlemlenmemiştir” (Tiles 1993, 465). Bu ani olmayan ayrışmayı destekleyecek en güzel örnekler Galileo, Newton ve Leibniz gibi isimlerin eserlerinde yer alan düşünce deneyleridir. Bazı isimler (Brown 1986; Kuhn 1994; McAllister 1996, ayrica 2004, 2005; Gendler 1998; Koyré 2007; Palmieri 2003) metinlerinde s1kça Galileo'nun eserlerinden alıntı yaparak, onun büyük bir deneyci olmasına rağmen yine de bilim tarihine düşünce deneylerinin en çarpıcı örneklerini sunduğunu kabul ederler.

Yakın tarihe gelindiğinde kuramcıları tarafından düşünce deneylerine sıklıkla başvurulan iki büyük alan görelilik kuramı (Brown 1991; Norton 1991, ayrıca 1993) ve kuantum mekaniğidir (Popper 1998; Bishop 1999). Einstein, Schrödinger ve Heisenberg gibi isimler bilim tarihinin en seçkin düşünce deneylerini ortaya koymuşlardır (Moue et al. 2006).

$\mathrm{Bu}$ ayrıntılı olmayan kısa tarihçe en azından düşünce deneylerinin bilim ve felsefe tarihinde oldukça yaygın olarak kullanıldığını göstermesi açısından önemlidir. Bazı görüşler düşünce deneylerinin kullanılışını Pre-Sokratiklere kadar dayandırırken, bazıları bu tarihlerde özgün bir düşünce deneyi örneğine rastlanmadığını savunmaktadır. Doğal olarak bu karşıt yorumlar tartışmayı tek bir soruya odaklamaktadır: Düşünce deneylerinin temel özellikleri nedir? Bu sorunun yanıtını aramak, belki bu tartışmaya nihai çözümü getirmese de, en azından düşünce deneylerinin yapısına ve işlevine bir ölçüde 1 şı tutacak ve hangi örneklerin bir düşünce deneyi olup olamayacağına ilişkin fikir edinmemize yardımcı olacaktır.

\section{Düşünce Deneylerinin Temel Özellikleri}

Tüm düşünce deneylerinin aralarında paylaştı̆̆ dört temel özellik vardır. Bu temel özelliklerden ilki düşünce deneylerinin zihnin laboratuvarında (Brown 1991) ya da daha sade bir deyişle düşüncede yürütüldügüdür. Bu özellik aynı zamanda gerçek deneyleri düşünce deneylerinden tanım itibariyle kolayca ayırabilmemizi sağlar. İkinci temel özellik, düşünce deneylerinin bir senaryoya, daha doğrusu bir anlatı formuna (narrative form) sahip olduğudur (Nersessian 1993, Gooding 1993). Bu anlatı aracılığıyla, deneyin nasıl bir düzene göre tasarlandığını ve bu düzene bağlı kalarak izlediğimiz belirli adımlardan hareketle ne tür sonuçlar elde edebileceğimizi görürüz. Üçüncü özellik, düşünce deneylerinin varsayımsal (hypothetical) ya da olgu karşıt1 (counterfactual) akılyürütmeler içerdiğidir (Rescher 1991, Norton 1991). Varsayımsal ve olgu karşıtı akıl yürütmeler aracılığıyla önümüze çıkabilecek teknik ve fiziksel engelleri ortadan kaldırarak gerçek bir deneye üstünlük sağlayabilir, onun barındırdığı pratik zorlukların ötesine geçebiliriz. Dördüncü ve son özellik ise, her düşünce deneyinin en nihayetinde bilimsel ya da felsefi bir soruya yanıt aramasıdır. Bu özellik sayesinde ancak bir düşünce deneyini örneğin edebi bir öyküden ayırt edebilmemiz için gerekli olan ölçütü belirleyebiliriz.

Elbette düşünce deneylerinin bu dört temel bileşen üzerine inşa edildiğini göstermek için örnekler üzerinden gitmek uygun bir yol olacaktır. Bu sebeple literatürde sıkça incelenen önemli bir düşünce deneyi örneğini ele alıp, sahip olduğu temel özellikleri nasıl sergilediğini göstermek 
istiyorum. Bunun için kullanacağım örnek birçok kişinin aşina olduğu ve neredeyse fizik, bilim felsefesi ve bilim tarihi ile ilgili birçok ders kitabında yer alan 'Pisa Deneyi' ya da bir başka adıyla 'Serbest Düşme Deneyi' olacak. Galileo, Pisa Deneyi'ni Discorsi isimli eserinde, Aristoteles'in evrendeki cisimlerin doğal yerlerine doğru, ağırlıklarıyla orantılı olarak, düştüğü iddiasına karşıt olarak geliştirmiştir. İlgili deney eserde şu şekilde yer alır:

Salviati: Fakat, ayrıca bir deney yapmadan, inandırıcı ve kısa bir argüman aracılığılla, Aristoteles'in söylediğine karşıt olarak, aynı malzemeden yapılma iki cisimden, daha ă̆ır olan cismin daha hafif olana göre hızlı hareket etmediğini, açık bir biçimde kanttlamak mümkündür [...] Ĕger doğal hızlarl farklı olan iki cismi ele alıp birleştirdiğimizde, daha hizl olan cismin daha yavaș olan cisim tarafindan yavaşlatılacağ şekilde daha yavaş olanın daha hizlı olan tarafindan hızlandırılacağl gayet açıktır. Sen de bu görüşe katılmıyor musun?

Simplicio: Kuşkusuz doğru söylüyorsun.

Salviati: Ancak ĕger bu doğruysa, ă̆ır taş diyelim ki sekiz, yavaş taş ise dört gibi bir hiza sahip olsun, bu iki cisim birleştirildiğinde, sistem sekizden daha düşük bir hızla hareket edecek; fakat bu iki taş bir araya getirildiğinde, sekiz gibi bir hıza sahip olan taştan daha ağır olacaktır. Bu yüzden, daha ağır cisim daha hafif olana göre daha yavaş hareket edecektir [ve bu] varsayımımıza karşıt bir sonuçtur. Böylece daha ağır cismin daha hafif olana göre hareket edeceği varsayımımızdan, daha ă̆ır cismin daha yavaş hareket ettiğini nasıl çıkarsadığımı görürüz. Buna bağlı olarak da, büyük ve küçük cisimlerin aynı özel yerçekimi sağlandı̆̆ında, aynı hıza sahip olacaklarını çıkarırız (Galileo 1632/1967, 62-63).

Şimdi yalın ama bir o kadar etkili bu diyaloğun, düşünce deneylerinin dört temel özelliğini, nas1l sergilediğini göstermek istiyorum.

(i) Deney düşüncede yürütülmüştür. Salviati'nin ağzından konuşan Galileo, ilk cümlesinde deney yapmamaktan söz ederken tam olarak bu duruma vurgu yapar. Yani deney düşüncede o kadar ikna edicidir ki, dış dünyada fazladan bir deney yürütmeye gerek duymayı.

(ii) Deney bir anlatı formuna sahiptir. Diyaloğun içerisinde kalıp neden-sonuç ilişkisini takip edilebiliyoruz ve deneyi tasarlayanın ulaşılmasını istediği sonuca ulaşılabiliyoruz. Şöyle ki, Galileo başta ağır olan cismin hafif olan cisme göre, daha hızlı hareket ettiği kabulünden yola çıkarak yavaş olan cismin hızlı olan cisim ile birleştirildiğinde onu yavaşlatacağını çıkarsamaktadır ve bu çıkarımı, karşıt görüşü savunan kişiye, yani Aristotelesçi Simplicio’ya teyit ettirmektedir. Buradan hareketle de, elde edilen birleşik cismin, birleştirilmeden önceki haline göre, daha ağır olmasına rağmen daha yavaş düştüğünü belirterek Aristotelesçi kabulde önemli bir sorun olduğunu göstermektedir.

(iii) Deney olgu karşıtı bir akılyürütme içermektedir. Salviati son cümlesinde, aynı özel yerçekiminin sağlanmasından bahsederken, olgu karşıtı bir akılyürütme gerçekleştirir. Bu ilk bakışta anlaşılması güç ve örtük bir ifade olarak gözükebilir ancak bu örtük ifadenin altında sözü edilen aynı özel yer çekiminin, özel bir duruma ya da bilindiği gibi sürtünmenin olmadığı bir ortama işaret ettiği açıktır. Eğer sürtünmenin olmadığı bir ortam sağlayabilseydik, ağırlıklarını hesaba katmadan tüm cisimlerin aynı hızla düştüğünü 
gözlemlerdik. Bu ifade olgu karşıtı akıl yürütmenin tipik bir örneğidir çünkü doğada sürtünmenin çok düşük olduğu ortamlar yaratılabilse de, sürtünmenin hiç olmadığı bir ortam bulunmamaktadır. Dolayısıyla söz konusu özel yer çekiminin dış dünyadaki günlük deneyimde karşılığ1 yoktur. Yani Salviati, ortamda bütünüyle sürtünmenin olmadığ 1 varsayıma dayanarak cisimlerin düşüşüne ilişkin bir yargıda bulunmaktadır.

(iv) Deney bilimsel bir soruya yanıt aramaktadır. Hız, ağılık ve hareket gibi kavramlara yanıt aramak genel olarak fiziğin özel olarak ise dinamiğin kapsamına girmektedir. Galileo, Aristotelesçi dinamik anlayışına, yani evrendeki her şeyin kendine özgü doğal bir yeri olduğu ve cisimlerin doğal yerlerine doğru ağırlıklarıyla orantılı olarak düştüğü kabulüne karşı bir düşünce deneyi yürüterek, bu kavramlarımızın revize edilmesinin gerekliliğini ortaya koymuştur.

\section{Düşünce Deneylerinin İşlevleri}

Düşünce deneylerinin bilimde birçok işlevi bulunmaktadır. Bu bölümde bunlardan önemli gördüğüm bazılarını bilim tarihinden örneklerle birlikte ele almak istiyorum.

Eleştirellik/Ylkıcılık Işslevi. Eleştirel ve yıkıcı işleve sahip düşünce deneylerinin özelliği "bir kurama karşı argüman geliştirmek" (Brown 1991, 34) ya da o kuramın içsel yapısının "saçma olduğunu göstermektir” (Popper 1998, 528). Bu işlevi Albert Einstein'ın 'Işsk Huzmesinin Takibi' olarak bilinen düşünce deneyi üzerinden göstermek istiyorum.

Micheal Faraday'ın elektrik alanlarının manyetik alanlar, manyetik alanların da elektrik alanları oluşturduğuna ilişkin kuramı elektromanyetizma olarak bilinmektedir. Daha sonraları bu kuramın matematiksel hesabını veren James C. Maxwell elektromanyetik dalgaların boşlukta yayılım hızının ışık hızına eşit olduğunu ispatlamıştır. Yani elektrik yüklü bir cisim titreştirildiğinde bu alandan kendisini koparan dalga, ışık hızına eşit bir hızla yayılmaktadır. Başka bir ifadeyle "[ $[1]$ şı dalgası için değişim esastır; ĕger elektrik ya da manyetik alan durağansa bir alan diğer alanı meydana getiremez ve böylece elektromanyetik dalga diye bir şey var olamaz" (Brown 1991, 15). Henüz on altı yaşındayken Einstein, Maxwell'in elektromanyetik dalga kuramının içsel yapısında bazı gariplikler olduğunu fark etmiş ve ışığın doğasına ilişkin bu garip durumu bir düşünce deneyi aracılığıyla açığa çıkarmıştır.

[E] ğer 'c' hızıyla (ışığın boşluktaki hızı) bir ışık huzmesini takip etseydim, bu ışık huzmesini, hareketsiz olarak uzayda titreşen elektromanyetik alan olarak gözlemlerdim. Hâlbuki böyle bir şey deneyime ya da Maxwell'in denklemlerine dayanarak mümkün gözükmemektedir (Einstein 1949, 53).

Einstein'ın elektromanyetik dalga kuramının içyapısında keşfettiği bu garip durumda kısa sayılabilecek bu düşünce deneyinin oynadığı rol açıkça ortadadır. Boş uzayda saniyede yaklaşık 300.000 kilometre yol alıp, Maxwell'in elektromanyetik dalga kuramını sınamak ancak böylesi bir düşünce deneyi aracıllğıyla mümkündür. Bu örnek Maxwell'in elektromanyetik dalga kuramındaki ciddi sorunu açığa çıkarması açısından düşünce deneylerinin eleştirel/yıkıcı işlevini nasıl işlediğini göstermektedir.

Buluşçu/Yapıcı İşlev. Düşünce deneylerinin eleştirel/yıkıcı işlevi bir kuramın iç yapısındaki kavramsal çelişkileri ortaya çıkarırken, buluşçu/yapıcı işlevi ise deneyden "artı sonuçlar elde etmeyi amaçlar” (Brown 1991, 36). Düşünce deneylerinin bu işlevini, Isaac Newton’un mutlak uzayın varlığını göstermek için zihninde tasarladığı 'Kova Deneyi' üzerinden anlatmak uygun olacaktır.

Newton'a göre, cisimlerin hareketinin referans noktası mutlak uzaydır. Başka deyişle, bu 
görüş hareketin uzayda bulunan diğer cisimlere göre değil, mutlak uzaya göre olduğunu savunmaktadır. Newton (1687/2004, 64-65) mutlak uzayı ve mutlak hareketi şöyle tanımlar: "Mutlak uzay, kendi doğasında, dışsal olanla hiçbir ilişsisi olamayan, hep aynı ve hareketsiz kalandır... Mutlak hareket bir cismin konumunun mutlak bir yerden diğerine doğru değişmesidir”.

Newton'un hareketin çevredeki nesnelere göre olmadığını ve buna ek olarak mutlak uzaya göre olduğunu gösterebilmesi için uzaydaki nesneleri yok etmesi gerekir. Yani deney ancak uzayda nesnelerin olmadığı bir düzen içerisinde yürütülebilir. Dolayısıyla burada bir düşünce deneyine gereksinim vardır. Newton düşüncede tasarladığı deney düzeninde elde ettiği sonucu şu sözlerle ifade etmektedir.

Mutlak hareketin, mutlak uzaydan farkını gösteren etkiler, döngüsel hareket ekseninden uzaklaşma kuvvetidir. Yalın bir biçimde, bu kuvvetler göreli döngüsel hareket için geçersiz iken mutlak hareket için hareketin niceliğine göre daha büyük ve daha küçük oranda doğrudur. Ĕger bir kovayı çok uzun bir ipe bağlarsak ve ipi sıkı bir hale gelene kadar devaml halde döndürürsek, bunun üzerine de kovaya su doldurup suyu kovaya göre mutlak dinginlikte tutarsak ve sonra birden ani bir kuvvetle ipi ters yöne doğru döndürerek, ipin çözülmesini sağladı̆̆ımızda ipin bu harekete bir süre direndiğini, sonraları kabın içerisindeki suyun başlarda hareket etmeden önceki dingin seviyede olduğunu görürüz. Fakat daha sonra, suyun üzerine gitgide etki eden kuvvetle kap, suyun ayrica algilanabilir şekilde dönmesine sebep olunca, su gitgide kabin orta tarafina çökecek ve kenarlara doğru yükselecek, konkav şekil göz önüne alındığında (ki deneyim bana bunu gösterdi) ve daimi hızlı hareketle daha da yükselecektir, ta ki devrini kap ile birlikte aynı zamanda bitirene ve kaba göreli olarak dinginliğe kavuşana değin. Suyun yükselişi, onun hareket ekseninden uzaklaşma çabasını açığa çıkarır, böyle bir çabadan her kimse, burada göreli hareketin doğrudan doğruya zıttı olan, suyun döngüsel gerçek ve mutlak hareketini çözebilir ve ölçebilir. Başlarda, kabın içerisindeki suyun göreli hareketi azami olduğu zaman, bu hareket eksenden uzaklaşmaya sebebiyet vermemişti; su kabın kenarlarından yükselerek dairenin çevresinde arayışta bulunmadı, fakat seviyede kaldl, böylece onun gerçek döngüsel hareketi henüz başlamamıştı. Fakat sonraları, ne zaman ki suyun göreli hareketi azald, onun kabin kenarlarına doğru yükselişi ve eksenden uzaklaşma çabası açı̆̆a çıktı, ve bu çaba gösterdi ki, suyun gerçek döngüsel hareketi devamlı artıyor ve en sonunda su kaba göre dingin durumdayken, azami seviyeye ulaşlyor. Böylece, o çaba [gösteriyor ki] suyun konumunun değişimi, çevredeki cisimlere göre bir bağımlllık taşımaz ve böylece gerçek döngüsel hareket, konumdaki bu gibi değişikler aracıllğıyla belirlenemez (Newton 1687/2004, 68).

Bu anlaşılması zor ve uzun pasaj daha açık bir şekilde yeniden şöyle ifade edilebilir. Düşünelim ki evrende su dolu bir kova hariç hiçbir nesne kalmadi. Bu kova, burulmuş hayali bir ip yard1mıyla aşağıya doğru sarkıtıldı. İlk olarak oluşturduğumuz su ve kova sisteminde, göreli bir hareket bulunmamaktadır. Başka bir ifadeyle "su ve kova arasında göreli bir hareket yoktur; yani suyun yüzeyi düz ve dingindir” (Brown 1991, 9). Daha sonra burulmuş ip yavaşça çözülmeye başlayacak ve kova göreli bir harekete kavuşacaktır. Su henüz hareketine başlamasa da yüzeyinde bir tür titreşim oluşacaktır. Son durumda ise, burulmuş ip iyice çözülmeye başlayacak ve 
suyun seviyesi başlangıcındaki durumundan farklı olarak iç bükey bir derinlik oluşturacaktır. Şimdi aniden kovayı durduğumuzu varsayalım. Gözlemleyeceğimiz şey kovanın durduğu, fakat suyun hâlen hareket ettiği olacaktır. Peki, kovanın içinde hareket halindeki su neye göre hareket etmektedir. Newton'a göre, evrende hiçbir şey kalmadığını ve kovayı da durdurduğumuzu da hesaba kattığımızda geriye yalnızca mutlak uzaya göre hareket ettiğini (yani mutlak uzaya bağlı bir hareketi) söylemekten başka uygun bir açıklama bulunmamaktadır. Brown'un ifadesiyle “mutlak hareketteki bu fark, su yüzeyindeki şeklin gözlemlediğimiz farkını açıklar. Bu varsayım üzerinden en iyi açıklama sunulur, şimdi mutlak uzayın varlığını kabul etmekten başka yolumuz yoktur" (Brown 1991, 9). Görüldüğü üzere Newton'un zihninde yürüttüğü bu deney yalnızca göreli hareket kuramının ve onun etkilerinin reddedilebileceğini göstermekle yetinmemiştir. Deney aynı zamanda artı bir sonuç elde ederek, düşünce deneylerinin buluşçu/yapıcı işlevinin de nasıl iş gördüğünü uygun bir biçimde göstermektedir.

Açıklama Gücü. Düşünce deneylerinin sahip olduğu bir diğer önemli işlev, bir doğa fenomenine açıklama getirmek ya da bir kuramın açıklama gücünü artırmaktır.

Bir doğa fenomenini genel olarak fiziksel bir deney aracılığıyla açıklarız. Fakat bazı durumlarda fiziksel deney yapabilmenin olanağı yoktur. $\mathrm{Bu}$ durumlarda düşünce deneyleri gerçek deneye uygun bir alternatif olarak görülmektedir. Örneğin Rescher (1991, 32), Thales'in yeryüzünün konumuna ilişkin görüşlerini öne sürerken, açıklayıcı varsayımlara dayanan düşünce deneyleri yürüttüğünü düşünmektedir. Ona göre şu çizgide bir akılyürütme formu, düşünce deneylerinin fenomenleri açıklama gücüne katkıda bulunur: " $X$ açıklaması zor bir durumdur, fakat eğer kesin olarak bilmediğimiz ama özünde mantıksı olmayan bir P'yi varsayarsak, X'in kusursuz biçimde iyi bir açıklamasını elde ederiz”. Ona göre oldukça iyi sayılabilecek ve açıklayıcı varsayımlara dayanan bu akılyürütme biçimi, Thales'te şu form ile gösterilebilir:

- Gösterilecek olan: yeryüzü suyun üzerinde yüzmektedir (tıpkı bir kütük gibi).

- Bunun böyle olduğunu varsayın, başka deyimle, varsayalım ki yeryüzü (bir kütük gibi) suyun üzerinde yüzmektedir.

- Bu varsayımın, yeryüzünün, doğa fenomenlerine dayanarak doğa içinde nasıl konumlandığını açıklayacağını (ve bunun en azından diğer alternatifler kadar iyi olduğunu) dikkate alın.

- O halde: yeryüzünün suyun üzerinde (bir kütük gibi) yüzdü̆g̈ü iddiamızı temellendirdik (Rescher 1991, 33).

Rescher'e göre Thales, üstte gösterildiği gibi yeryüzünün doğa içerisinde nasıl bir pozisyona sahip olduğuna, makul bir varsayıma dayanarak, iyi bir açıklama getirmektedir. Yeryüzünün tıpkı bir kütük gibi suyun üzerinde yüzdüğü varsayımı Rescher için bir düşünce deneyidir ve bu deney aracılığıyla yeryüzünün konumu son derece iyi bir biçimde açıklanmıştır.

Düşünce deneyleri bazı durumlarda bir doğa fenomenine uygun bir açıklama getirmekle yetinmez, aynı zamanda o fenomenin "bağlı olduğu kuramın açılama gücünü artırmak için tasarlanabilir" (Lennox 1991, 223). Örneğin Charles Darwin'in magnum opus'u 'Türlerin Kökeni'nde, yaşam için mücadele etmenin seçilim aracılığıyla organizmada çeşitlilik üretebildiği konusunda açıklayıcı bir görüş ortaya koymak ve kuramının açıklama gücünü artırmak amacıyla yürüttüğü şu düşünce deneyini ele alalım:

[D]oğal seçmenin nasıl etkide bulunduğunu aydınlatmak için, birkaç tasarlanmıs örnek vermeme izninizi dilerim. Türlü hayvanları avlayan, 
avlarının bazısını hileyle, bazısını kuvvetle, bazısını da çeviklikle ele geçiren kurdu ele alalım; ve en çevik avın, örneğin geyiğin, herhangi bir değişiklik yüzünden çevrede pek çoğaldiğını, ya da kurdun en çok besin sıkıntısı çektiği bir mevsim boyunca, bir başka av hayvanının azaldı̆̆ını varsayalım. Böyle şartlarda en çevik ve en ince yapılı kurtların săg kalma şansı pek artar ve bunlar, bu yüzden saklanır ya da seçilirdi, -yeter ki başka hayvanları avlamak zorunda olduklarl yılın öbür dönemlerinde avlarıyla baş edebilecek kadar güçlü kaldıkları öngörülsün (Darwin 1970, 93).

Darwin’in, zihninde tasarladığı bu deneyde açıklamak istediği şey, çevik ve ince yapılı kurtların, besin bolluğunun ya da tam tersi besin sıkıntısının yaşandığı bir çevrede, neden sağ kalacağıyla ilgilidir. Darwin'in bu düşünce deneyi, Thales'in düşünce deneyinden, bir arka plan kuramına sahip olması bakımından farklılaşır. Thales'in yürüttügü düşünce deneyinin, hiçbir arka plan kuramına dayanmaması olağandır çünkü onun yaşadığı dönemde günümüzde bilimsel kuram dediğimiz şeyin olmamasını bir kenara bırakın, bilimin kendisinin bile günümüz biliminden çok farklı olduğunu söyleyebiliriz. Diğer taraftan Darwin'in tasarladığı düşünce deneyi kuramıyla sıkı bir ilişki içerisindedir. Başka deyişle "belirli bir yöndeki tesadüfì değişimlerin farklı çeşitlilikler, sonunda ise yeni türlerin oluşturacağına ilişkin [varsayımlar] Darwin'in kuramının mekanizması ve işleyişi ile doğrudan ilişsilidir” (Lennox 1991, 229). Fakat bu farklılı̆̆ın ötesinde iki örneğin düşünme biçiminin benzerliği hakkında yorum yapabilmenin önünde bir engel olduğunu düşünmüyorum. Örneğin, ele aldığım iki düşünce deneyinin de en iyi açıklamaya doğru yapılan çıkarım (inference to the best explanation) olduğunu söyleyebilirim. Yani her iki yaklaşım, ele aldıkları fenomenleri, arkasında bıraktığı diğer alternatif görüşlerinden daha iyi açıklamaktadır. Başka deyişle yeryüzünün konumunu mitolojik bir karakter yardımıyla açıklamak ya da seçilimi ve korunumu yaratıcının keyfi kararları olduğunu kabul etmek, bizi titanların gücünün ya da tanrının kararlarının ne olduğuna ilişkin farklı problemlere götürecektir. Dolayısıyla bir doğa fenomenini açıklamak için en iyi aday bu ikisi değil, Thales'in ve Darwin'inkilerdir. Özetle söylemek gerekirse, düşünce deneylerinin bir fenomeni açıklamak için tasarlanması bilimde oldukça sık rastlanan bir durumdur. Elbette bu deneylerin bir kuramın ilişkisini açıklamada oynadığg rol, bağlı olduğu kuramın çerçevesinde yapılmalıdır. Nitekim ancak bu şekilde elde edilen sonuçlar tekrardan test edilen kurama yönelik bir şeyler söyleyebilir.

İdealizasyon. Fiziksel deneyin yürütülmesi sürecinde deneycilerin karş1laştıkları birçok sorun bulunmaktadır. Örneğin gerçek bir deneyde kullanılacak gereçler, her zaman beklenildiği gibi düzgün çalışmayabilir ya da çevresel koşullar deney düzeneğinin uygun bir biçimde kurulabilmesine engel olabilir. Buna benzer birçok zorluğun düşünce deneyleri üzerinde etkisi yoktur çünkü düşünce deneylerinin önemli bir işlevi de belirli bir doğa durumunun ötesine geçmemize, onu idealize etmemize olanak tanımasıdır. Bu işlevi Simon Stevinus'un 'Hareketsiz Zincir' olarak bilinen düşünce deneyi üzerinden anlatmak uygun olacaktır.

On altıncı yüzyılda yaşamış olan mühendis Stevinus eğimli düzlemlerin mekaniği üzerine ayrıntılı çalışma yapmış ilk kişidir. Yaşadığı döneme kadar cisimlerin dikey düzlemlerde hareketli, yatay düzlemlerde ise, hareketsiz olacağı bilinmektedir. Ancak dikey ve yatay konumun ara durumunda, yani eğimli düzlemde, cisimlerin nasıl bir harekete sahip olacağına ilişkin kesin bir sonuç verilememiştir. Elbette eğimli düzlemde cismin hareket edeceği ama dikey düzleme göre daha düşük bir hıza sahip olacağı açıktır; çünkü eğimli bir düzlem yarı dikey ve yarı yatay bir pozisyona sahiptir. Fakat eğimli düzlemler için hareketin bu derece belirgin olmadığ 
durumlar da vardır. Örneğin bir kenarı zemine paralel eşkenar olmayan bir üçgen prizmanın iki eğimli yüzeyi bulunmaktadır. Stevinus cisimlerin, birbirine bir noktada değen eğimli düzlemlerde nasıl hareket edeceğine ilişkin neler söyleyebileceğimizi tasarlamamızı ister ve bir düşünce deneyi önerir. Bu düşünce deneyi, üçgen prizmanın iki eğimli kenarının bitim noktalarına kadar uzanan bir zincir bırakıldığında oluşabilecek durumunun ne olacağını gözlemlemek için tasarlanmıştır. "Ü̧̧ olasılık bulunmaktadır: [Zincir] hareketsiz kalacaktır; sola doğru kayacaktır, çünkü belki o taraf daha fazla kütleye sahip; ya da sağa doğru kayacaktır, çünkü belki o taraf daha dik bir eğime sahiptir. Stevin'in yanıtı ilk olandır: [yani zincir] hareketsiz denge durumunda kalacaktır" (Brown 1991, 3).

Stevinus ilk olasılığı kabul eder yani eğimli düzlemde zincir hareketsiz kalacaktır. Bu görüşünü temellendirmek için zincirin iki açık ucuna yine aynı malzemeden yapılma bir zincir parçası eklememizi ister. Böylece üçgen prizmanın çevresinde ucu kapalı halka bir zincir oluşacaktır. Stevinus bu yeni durumu referans alarak zincirin sağa ya da sola doğru gerçekleşecek herhangi bir hareketinin sonu gelmeyen bir harekete yani sınırsız bir harekete 'perpetuum mobile' yol açacağı sonucuna ulaşır. Zincirin sınırsız bir harekette bulunması "[S]tevinus'a göre saçmadır. Bu nedenle yalnızca ilk durum akla yatkındır" (Mach 1919, 25). Ancak akla yatkın ilk durumun geçerli olabilmesinin tek koşulu bazı durumların düşünce deneyi aracılığıyla idealize edilebilmesine bağlıdır. Örneğin Stevinus bu nedenle düzlemin sürtünmesiz kabul edilmesi gerektiğini baştan belirtmektedir; çünkü sürtünmenin olduğu bir düzlemde yüzeyin ihmal edilmeyecek bir etkisi hareketin üzerinde değişikliğe yol açabilir.

Birçok düşünce deneyi idealizasyon içerir. Bishop (1998) düşünce deneylerinin idealizasyon olduğunu ve gerçek dünyanın doğasında bulunan karmaşık zorlukların ya da pratik olanaksızlıkların aşılabilmesini sağladığını düşünmektedir. Her ne kadar idealizasyonlar sayesinde karmaşık zorlukları ya da pratik olanaksızlıkları aşsak da tüm düşünce deneylerinin idealizasyon içerdiğini söylemek güçtür. Özellikle etik ile ilgili bazı düşünce deneyleri, kendisinden ahlaki sonuç çıkarabilmemiz için genelde gerçek dünyadaki yapının sınırları dışına çıkmayan deney tasarımlarına sahiptir. O halde burada sınırımızı bilimdeki düşünce deneyleri ile çizmek uygun olacaktır.

\section{Değerlendirme}

Bu yazıda düşünce deneylerinin kavramsal ve tarihsel arka planını oluşturmaya çalıştıktan sonra bu deneylerinin sergilediği temel özellikleri irdeledim. Bu özelliklerin neler olduğunu açığa çıkarma girişimi bana kalırsa oldukça önemli olsa da bazı iddialar bunun tersini öne sürmektedir. Örneğin bazı görüşlere göre düşünce deneylerinin ne olduğunu kesin bir biçimde söylemek zordur ve bunun pek de önemi yoktur. Bu görüşe kısmen katıldığımı söyleyebilirim çünkü düşünce deneylerinin ne olduğuna ilişkin kesin bir yargıda bulunmak güçtür. Ancak bu durumun önemli olmadığg fikri bütünüyle doğru gözükmemektedir. Elbette düşünce deneylerinin kesin bir tanımını veremeyiz çünkü bu onu hangi özelliğini göz önüne alarak tanımlayacağımıza bağlıdır. Fakat en azından bu zihinsel etkinliklerin sergilediği temel özellikleri tanımlamak, herhangi bir örneğin neden bir düşünce deneyi olduğuna ilişkin bilgi sahibi olmamıza yardımcı olup, onu düşünce deneyi olmayan bir örnekten ayırmamıza olanak tanıyabilir. Son bölümde düşünce deneylerinin dört farklı işlevini, örnekler üzerinden, anlatmaya çalıştım. Düşünce deneylerinin sahip olduğu eleştirel ya da yıkıcı işlev sayesinde bir kurama karşı argüman geliştirilebilir ve o kuramın içsel yapısının saçma olduğunu gösterilebilir, buluşçu ya da yapıcı işlevi sayesinde deneyden artı sonuçlar elde edilebilir, açıklayıcı işlevi sayesinde bir doğa fenomeni açıklanabilir ya da bir kuramın açıklama gücünü artırılabilir, idealize edebilme işlevi sayesinde ise, gerçek dünyanın doğasında bulunan karmaşık zorluklar ya da pratik olanak- 
sızlıklar aşılabilir. Şüphesiz düşünce deneylerinin farklı birçok işlevi bulunmaktadır. Örneğin son yıllarda, uygulamalı istatistikte, bazı düşünce deneylerinin herhangi bir kuramı hedeflemeyip yalnızca kuramın ya da modelin uygulanabilirliği için kavramsal çerçeve yarattığı öne sürülmektedir. Bu ve buna benzer işlevlerin ortaya çıkarılması düşünce deneylerinin doğasına ilişkin araştırmamızda aydınlatıcı olacaktır.

Son olarak bu yazıda düşünce deneylerinin epistemolojik statüsüne, bilim eğitiminde oynadığı olumlu role, bilim komiteleri arasında sağladığı güçlü iletişime ve sahip olduğu bilişsel etkiye değinilmediğini belirtmek isterim. Bunun nedeni söz konusu meselelerin önemsizliğinden değil, aksine bu konuların başlı başına bir makalenin konusu olabilecek genişlikte olmasıdır. Düşünce deneylerinin felsefe ve bilim tarihi boyunca sıklıkla başvurulan bir deney türü olduğu hesaba katıldığında söz konusu meselelerin ayrıca ele alınmasının önemini bu anlamda bir kez daha vurgulamak gerekiyor.

\section{KAYNAKÇA}

Bishop M. (1998). “An Epistemological Role for Thought Experiments”. Ed. N. Shanks. Idealization IX: Idealization in Contemporary Physics (1998) 19-33. Amsterdam/Atlanta.

Bishop M. (1999). "Why Thought Experiments are Not Arguments”. Philosophy of Science 66 (1999) 534-541.

Brown J. R. (1986). “Thought Experiments since the Scientific Revolution”. International Studies in the Philosophy of Science 1 (1986) 1-15.

Brown J. R. (1991). Laboratory of the Mind: Thought Experiments in the Natural Sciences. London 1991.

Darwin C. (1970). Türlerin Kökeni. Çev. Öner Ünalan. Ankara 1970.

Duhem P. (1954). The Aim and Structure of Physical Theory. Princeton 1954.

Einstein A. (1949). “Autobiographical Notes”. Ed. Schilpp, A. Albert Einstein: Philosopher-Scientist, La Salle.

Galileo G. (1632/1967). Dialogue Concerning the Two Chief World Systems. Çev. S. Drake. University of California Press, Berkeley 1632/1967.

Gendler T. S. (1998). "Galileo and the Indispensability of Scientific Thought Experiment”. The British Journal for the Philosophy of Science 49 (1998) 397-424.

Gilbert J. \& Reiner M. (2004). "The symbiotic roles of empirical experimentation and thought experimentation in the learning of physics”. International Journal of Science Education 26/15 (2004) 1819-1834.

Gooding D. C. (1993). “What is Experimental About Thought Experiments?”. Proceedings of the Philosophy of Science Association 2 (1993) 280-290.

Grant E. (2010). The Nature of Natural Philosophy in the Late Middle Ages. Washington 2010.

Ierodiakonou K. (2005). “Ancient Thought Experiments: A First Approach”. Ancient Philosophy 25 (2005) $125-140$.

Ierodiakonou K. (2011). "Remarks on the History of an Ancient Thought Experiment”. Eds. Sophie Roux \& Katerina Ierodiakonou. Thought Experiments in Methodological and Historical Contexts 15 (2011) 37-49. Leiden.

King P. (1991). "Mediaeval Thought-Experiments: The Metamethodology of Mediaeval Science”. Eds. Horowitz, T. and Massey, G. Thought Experiments in Science and Philosophy (1991) 43-64. Lanham.

Koyré A. (2007). Bilim Tarihi Yazıları. Çev. Kurtuluş Dinçer. Ankara 2007.

Kuhn T. S. (1994). Asal Gerilim. Çev. Yakup Şahan. İstanbul 1994.

Lennox J. G. (1991). "Darwinian Thought Experiments: A Function for Just-So Stories”. Eds. Horowitz, T. and Massey. Thought Experiments in Science and Philosophy (1991) 223-245. Lanham.

Lennox J. G. (1991). "Darwinian Thought Experiments: A Function for Just-So Stories". Eds. Tamara Horowitz and Gerald J. Mossey. Thought Experiments in Science and Philosophy (1991) 223-245. 
Savage, MD.

Mach E. (1897/1973). “On Thought Experiments”. Çev. Krimsky, S. \& Price, W. D. Philosophical Forum 4/3 (1897/1973) 446-457.

Mach E. (1919). The Science of Mechanics. Çev. J. McCormack. LaSalle Illinois 1919.

McAllister J. (1996). “The Evidential Significance of Thought Experiments in Science”. Studies in History and Philosophy of Science 27 (1996) 233-250.

McAllister J. (2004). “Thought Experiments and the Belief in Phenomena”. Proceedings of the 2002 Biennial Meeting of the Philosophy of Science Association, Philosophy of Science 71 (2004) 11641175.

McAllister J. (2005). "The Virtual Laboratory: Thought Experiments in Seventeenth-Century Mechanics”. Eds. H. Schramm et al. Collection, Laboratory, Theater: Scenes of Knowledge in the $17^{\text {th }}$ Century (2005) 35-56. New York.

Moue A. S., Masavetas K. A. \& Karayianni, H. (2006). "Tracing the Development of Thought Experiments in the Philosophy of the Natural Sciences”. Journal for General Philosophy of Science 37 (2006) 61-75.

Nersessian N. (1993). "In the Theoretician's Laboratory: Thought Experimenting as Mental Modeling”. Proceedings of the Philosophy of Science Association 2 (1993) 291-301.

Newton I. (1687/2004). “The Principia”. Ed. Andrew Janiak. Philosophical Writings. Cambridge (1687/2004).

Norton J. D. (1991). “Thought Experiments in Einstein's Work”. Eds. T. Horowitz and G. Massey. Thought Experiments in Science and Philosophy (1991) 129-148. Lanham.

Norton J. D. (1993). "Einstein and Nordström: Some Lesser Known Thought Experiments in Gravitation”. Eds. John Earman et al. The Attraction of Gravitation: New Studies in History of General Relativity (1993) 3-29. Boston.

Palmieri P. (2003). "Mental models in Galileo's early mathematization of nature”. Studies in History and Philosophy of Science 34 (2003) 229-264.

Popper Karl R. (1998). Bilimsel Araştırmanın Mantı̆̆ı. Çev. İbrahim Turan ve İlknur Aka. İstanbul 1998.

Rescher N. (1991). “Thought Experiments in Presocratic Philosophy”. Eds. T. Horowitz and G. Massey. Thought Experiments in Science and Philosophy (1991) 31-42. Lanham.

Tiles J. E. (1993). "Experiment as Intervention". British Journal for Philosophy of Science 44 (1993) 46375.

Witt-Hansen J. (1976). “H. C. Orsted, Kant and The Thought Experiment”. Danish Yearbook of Philosophy 13 (1976) 48-56. 